\title{
Alkaline Phosphatase in Dictyostelium discoideum
}

\author{
By KERSTIN GEZELIUS* AND BARBARA E. WRIGHT \\ From the John Collins Warren Laboratories of the Huntington Memorial Hospital \\ of Harvard University, at the Massachusetts General Hospital, Boston, Mass, U.S.A.
}

(Received 26 May 1964)

\begin{abstract}
SUMMARY
Several phosphatases have been demonstrated in Dictyostelium discoideum. The alkaline phosphatase, $\mathrm{pH}$ optimum $9 \cdot 0$, is a $5^{\prime}$-nucleotidase, attacking adenosine monophosphate and deoxyadenosine monophosphate, but catalyses also hydrolysis of $p$-nitrophenyl phosphate. In the absence of exogenous nutrients this enzyme increases about 6 -fold in vitro during differentiation. Its activity in vivo may in part be controlled through endproduct inhibition by orthophosphate which has been found to accumulate in the cells during sporulation. Exogenous orthophosphate and glucose repress the levels of alkaline phosphatase in the spores. The data support the conclusion that end product inhibition and repression collaborate to ensure maximal alkaline phosphatase activity in vivo during culmination. Exogenous adenosine and deoxyadenosine increase the alkaline phosphatase levels in the sorocarps.
\end{abstract}

\section{INTRODUCTION}

Histochemical and in vitro studies on the differentiating cellular slime mould Dictyostelium discoideum have shown that the enzyme alkaline phosphatase changes in activity during the development of the organism. The activity increases until spore formation but decreases to a minimum in the mature fruiting bodies or sorocarps (Bonner, Chiquoine \& Kolderie, 1955; Krivanek, 1956). These studies were performed with $\beta$-glycerophosphate as substrate at $\mathrm{pH} 9 \cdot 3$. With adenylic acid at pH 8·3, Krivanek \& Krivanek (1958) found a similar activity pattern for $5^{\prime}$ nucleotidase. It has been shown (Wright, 1960) for other slime mould enzymes that apparent increases in in vitro activities during differentiation may be due to rapid inactivation in extracts prepared at the early stages of development and thus do not represent true increases in enzyme concentrations. In the event that true increases are shown to occur, these do not necessarily reflect increased enzyme activities in vivo, where, e.g. changes in substrate and inhibitor concentrations may control the reactions. The present investigation was, therefore, undertaken to determine if the observed changes in alkaline phosphatase activity in vitro reflect the conditions inside the living cells.

During this work a number of phosphatases have been detected, distinguishable from each other through $\mathrm{pH}$ optima, $\mathrm{Mg}^{2+}$ requirements and their in vitro activities at the various stages of differentiation, They include, besides the alkaline phosphatase, one acid phosphatase, optimum about pH 3.5, one ATP (see p. 312) attacking enzyme, two pyrophosphatases with optima at $\mathrm{pH} 6.2$ and 8.8 and one enzyme,

* Present address: Institute of Physiological Botany, University of Uppsala, Uppsala, Sweden. 
active on $5^{\prime}$-GMP, with optimum at $\mathrm{pH} 7 \cdot 5-8 \cdot 5$. The present paper will describe the alkaline phosphatase and only include the other enzymes when necessary for distinguishing purposes. The other phosphatases will be dealt with in subsequent papers. For a full description of the life cycle of the slime mould the reader is referred to Bonner's monograph, The Cellular Slime Molds (1959). A summary is presented in Fig. 1.

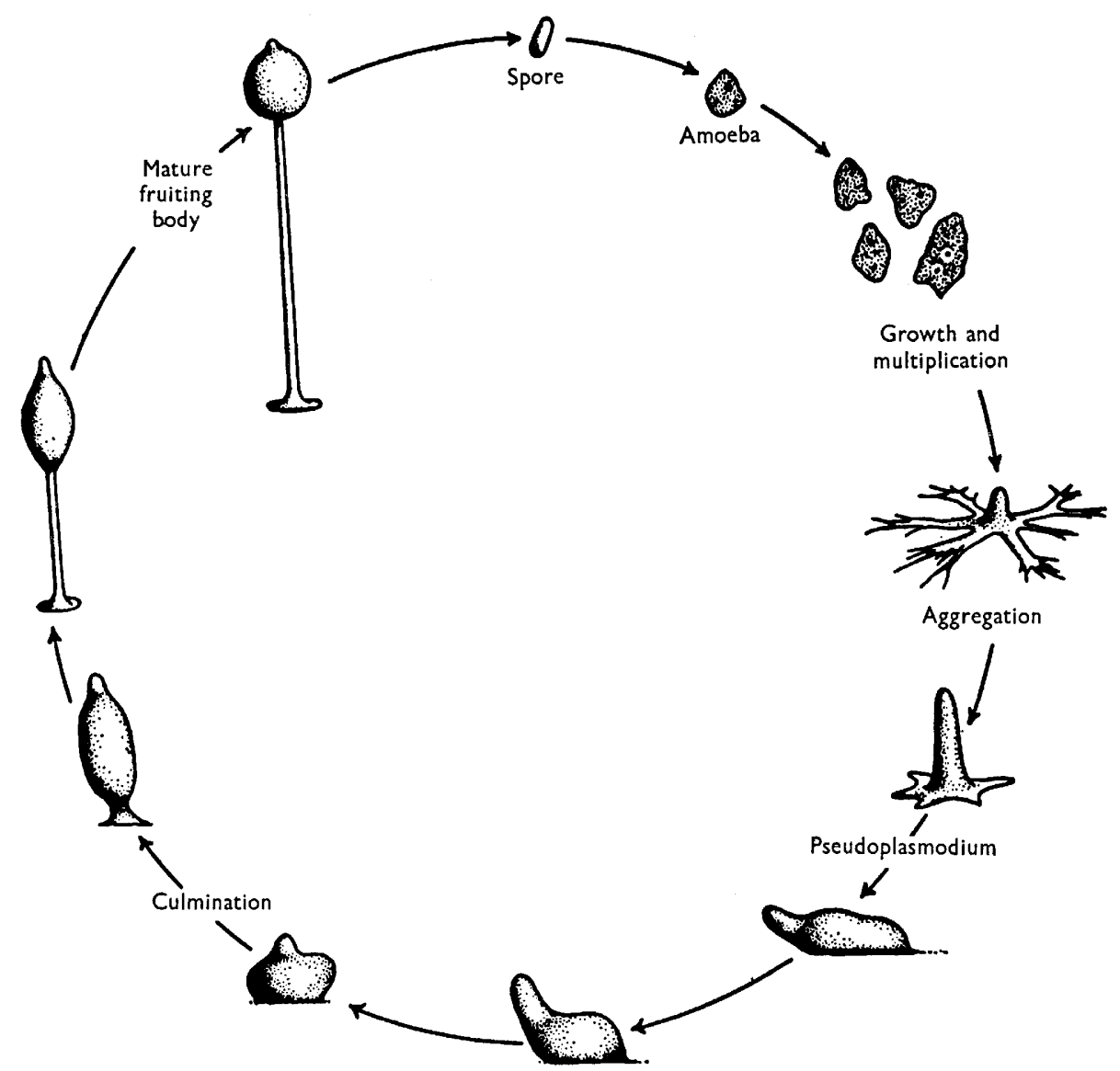

Fig. 1. Life cycle of Dictyostelium discoideum.

\section{METHODS}

The myxamoebae of Dictyostelium discoideum strain NC-4 were grown at $23^{\circ}$ on SM agar (Sussman, 1961) with Escherichia coli strain ML 304d, washed and transferred to $2 \%$ plain agar for starvation and multicellular differentiation at $17^{\circ}$ as described by Liddell \& Wright (1961). Compounds studied in induction and repression experiments were included in the $2 \%$ agar. For comparison, in one experiment the slime mould was allowed to differentiate on the complex medium in the presence of residual food bacteria.

The enzyme activities were studied in crude cell-free extracts. At the desired stage of development the slime mould was harvested from the agar with $0 \cdot 01 \mathrm{M}$-tris 
buffer ( $\mathrm{pH}$ 7.2). The suspension was homogenized in an Aminco (American Instrument Corporation, Silver Spring, Md, U.S.A.) French pressure cell at $5000 \mathrm{lb}$./sq. in. and the homogenate centrifuged at $3000 \mathrm{~g}$. for $10 \mathrm{~min}$. All these procedures were undertaken in the cold. The protein content in the extracts was usually about $10 \mathrm{mg} . / \mathrm{ml}$.

Protein was determined by the modified micro-biuret method (Zamenhof, 1957) with crystalline serum albumin as a standard. The measurements were performed in a Zeiss spectrophotometer Model PMQ II. The determinations were made either on the crude extracts or after precipitation of the protein in $3.5 \%(\mathrm{w} / \mathrm{v})$ perchloric acid followed by dissolving of the precipitate in $0.5 \mathrm{M}-\mathrm{NaOH}$. The latter procedure was necessary when the experiments involved a comparison between different developmental stages because of the varying size of the amino acid pool and of the small peptide pool during differentiation (Wright, 1964).

Intracellular orthophosphate. To avoid washing out phosphate from the cells during the harvesting procedure, at different stages the organism was removed from the agar surface with a glass slide and suspended in cold 0.01 $\mathrm{M}$-tris ( $\mathrm{pH} \mathrm{7 \cdot 2).} \mathrm{At}$ the sorocarp stage determinations were made both on the whole fruiting bodies and on the spores.

A sample of the fresh suspension was immediately extracted for $\mathbf{3 0} \mathrm{min}$. in cold $5 \%$ trichloroacetic acid (TCA). After centrifugation the orthophosphate in the supernatant fluid was determined according to the method of Fiske \& SubbaRow (1925) as modified by Dryer, Tammes \& Routh (1957).

Another sample of the suspension was centrifuged for $10 \mathrm{~min}$. at $1000 \mathrm{~g}$, giving the corresponding volume of packed organism (Wright \& Bard, 1963). The intracellular phosphate concentration was expressed as molarity in terms of packed cell volume.

Enzyme assays. The alkaline phosphatase activity was assayed in diluted extracts (about $0.1 \mathrm{mg}$. protein $/ \mathrm{ml}$.) with $p$-nitrophenyl phosphate (NPP) as substrate (Torriani, 1960) unless specified otherwise. The reaction was followed spectrophotometrically (Beckman DU or Zeiss PMQ II) at $23^{\circ}$ by the formation of nitrophenol (NP) at $420 \mathrm{~m} \mu$.

The reaction mixture, $1 \mathrm{ml}$, was 0.05 or $0.5 \mathrm{M}$-tris $(\mathrm{pH} \mathrm{9}), 0.02 \mathrm{M}-\mathrm{MgCl}_{2}$, $0.01 \mathrm{M}$-NPP. In the early experiments, where $0.5 \mathrm{M}$-tris was used, no $\mathrm{MgCl}_{2}$ was added, and it was also omitted in the experiments on phosphate inhibition. The amount of crude enzyme added corresponded to 5-50 $\mu \mathrm{g}$. protein $/ \mathrm{ml}$. The enzymespecific activity was calculated from the initial rapid reaction rate and expressed as a $\mu \mathrm{Mmole} \mathrm{NP} / \mathrm{min} . / \mathrm{mg}$. protein. Figs. $7-11$ express activity in these terms; comparative data on substrate specificity, $\mathrm{pH}$ optima, etc., are expressed as per cent of maximal activity.

The hydrolysis of other phosphate compounds was determined as theamount of orthophosphate ( $\mathbf{P i})$ released, and the specific activity expressed as $\mu \mathrm{Mmole} \mathrm{Pi} / \mathrm{min} . / \mathrm{mg}$. protein. The reaction mixture was $0.05 \mathrm{M}$-tris, $0.02 \mathrm{M}-\mathrm{MgCl}_{2}$ (except as noted) and $0.01 \mathrm{M}$ with respect to substrate concentration. The incubation time was $15 \mathrm{~min}$. to $1 \mathrm{hr}$, occasionally longer, and the temperature was $23^{\circ}$. The reaction was stopped through addition of cold $30 \%$ TCA to final concentration $6 \%$. The Pi was determined according to Dryer et al. (1957). Control tubes without enzyme were incubated in all experiments. 
The hydrolysis of 5'-AMP was determined also as the amount of adenosine formed (Herman \& Wright, 1959). The reaction was stopped by addition of $10 \%$ TCA to final concentration $2 \%$. After centrifugation, samples $(0.03 \mathrm{ml}$.) of the supernatant fluid were assayed with adenosine deaminase in a total of $1.1 \mathrm{ml}$. of $0.05 \mathrm{M}$-phosphate

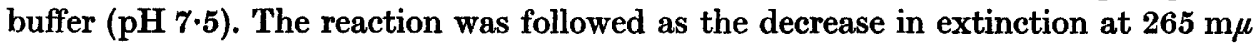
in the Zeiss (Kornberg \& Pricer, 1951).

Reagents. NPP, NP, $\beta$ GP, G6P, GIP, FDP, 5 '-UMP, 5'-CMP, GTP (type II, 95-98\%), GDP, UDP, adenosine, deoxyadenosine, and adenosine deaminase (type II, crude powder) were obtained from Sigma Chemical Company, St Louis, Mo, U.S.A.; 5'-GMP, 5'-TMP, ADP and UTP from Pabst Laboratories, Inc., Milwaukee, Wisc., U.S.A.; 5'-AMP and ATP from Sigma and Pabst; 5'-IMP and 5'-dAMP from California Corporation for Biochemical Research, Los Angeles, Calif., U.S.A.; and 3'-AMP from Schwarz BioResearch, Inc., Mount Vernon, N.Y., U.S.A. With the exception of GTP and adenosine deaminase, all compounds were reagent grade.

The following abbreviations are used throughout this paper: NPP, $p$-nitrophenyl phosphate; NP, nitrophenol; Pi, orthophosphate; $\beta$ GP, $\beta$-glycerophosphate; G 6P, glucose-6-phosphate; G1P, glucose-1-phosphate; FDP, fructose-1,6-diphosphate; 5'-AMP, 5'-GMP, 5'-CMP, 5'-UMP, 5'-TMP, and 5'-IMP, the 5'-monophosphates of adenosine, guanosine, cytidine, uridine, thymidine and inosine respectively; 5'-dAMP, deoxyadenosine-5'-monophosphate; 3'-AMP, adenosine-3'-monophosphate; ATP, GTP, UTP, ADP, GDP, UDP, the tri- and diphosphates of adenosine, guanosine and uridine; $\mathrm{PPi}$, pyrophosphate; tris, tris(hydroxymethyl)aminomethane; and TCA, trichloroacetic acid.

\section{RESULTS}

The stages usually studied were amoeba (starved for 2-3 hr), pre-culmination; culmination and sorocarp (about 10-15 hr after sorocarp formation). The time required for sporulation varied between the experiments depending on the status of the amoebae at the time of transfer from the rich medium, variations in washing and plating procedures, and so on.

$p H$ optimum. As shown in Fig. 2 optimal phosphatase activity against NPP was obtained at $\mathrm{pH} \mathrm{9.0}$ in extracts prepared either at the amoeba or sorocarp stage.

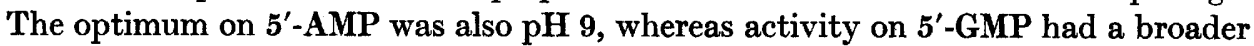
optimum around $\mathrm{pH}$ 8. This fact and other data (see below) indicate that $5^{\prime}$-GMP is not a substrate for alkaline phosphatase.

Substrate concentration. The effect of increasing substrate concentration on phosphatase activity against NPP and $5^{\prime}$-AMP is shown in Fig. 3. The optimal concentration range was the same for both compounds.

$\boldsymbol{M g}^{2+}$ activation. The phosphatase was more dependent on $\mathrm{Mg}^{2+}$ ions when assayed in a final concentration of $0.05 \mathrm{M}$-tris than when $0.5 \mathrm{M}$-tris was used. With dialysed extracts about $75 \%$ of maximal activity against NPP was obtained in 0.5 $\mathrm{M}$-tris without addition of $\mathrm{Mg}^{2+}$ compared to $50 \%$ at the lower buffer concentration (Fig. 4). A similar relationship between buffer concentration and $\mathbf{M g}^{2+}$ activation has been reported for the alkaline phosphatase of Escherichia coli (Garen \& Levinthal, 1960). Optimal $\mathrm{Mg}^{2+}$ concentration in 0.05 $\mathrm{M}$-tris was 0.02-0.05 $\mathrm{M}$ at 
amoeba and sorocarp stages, with either NPP or $5^{\prime}$-AMP as substrate. (In the curve for AMP the activity without $\mathrm{Mg}^{2+}$ is higher than that usually obtained as in Table 3.) In contrast, activity on $\mathbf{5}^{\prime}$-GMP was completely dependent on $\mathbf{M g}^{2+}$ implicating another enzyme (see below).

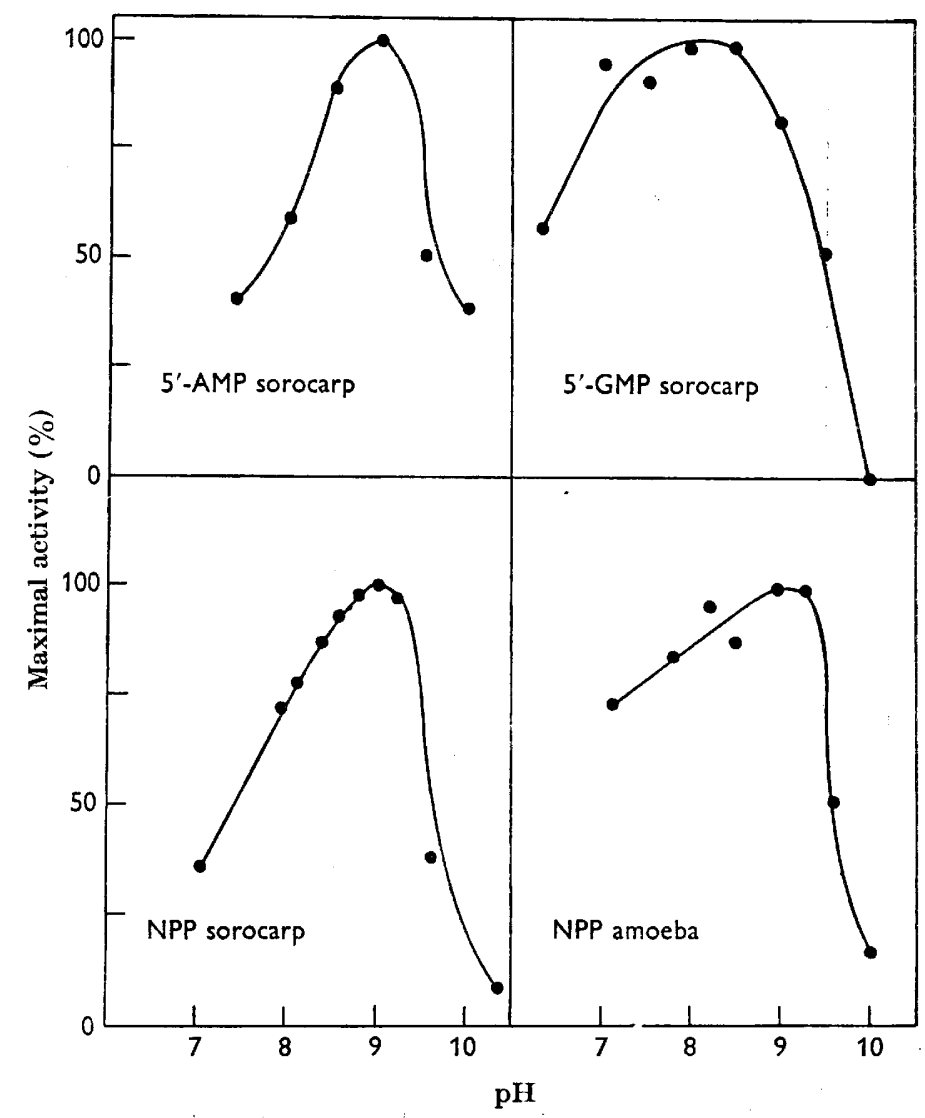

Fig. 2. Effect of pH on phosphatase activity against NPP (bottom), 5'-AMP and $5^{\prime}$-GMP (top). The activities against NPP were assayed in $0.5 \mathrm{M}$-tris without $\mathrm{MgCl}_{2}$, those against $5^{\prime}$-AMP and $5^{\prime}$-GMP in $0.05 \mathrm{M}$-tris, $0.02 \mathrm{M}-\mathrm{MgCl}_{2}$. They are expressed in percent of maximal activity obtained.

Distribution of enzyme activity in vitro during differentiation. The alkaline phosphatase activity in vitro increased about 5-7 times during differentiation. The activity was highest in the sorocarps and the major increase took place during culmination (Table 5).

Since some bacteria were always transferred to the plain agar with the amoebae, and since the amoebae, even after starvation for $\mathbf{2 - 3} \mathrm{hr}$, still might contain engulfed Escherichia coli in various states of disintegration, the phosphatase activity measured in the amoeba extracts might have been derived in part from bacterial enzyme. No phosphatase activity, however, was demonstrable in the $\boldsymbol{E}$. coli mutant strain used when it was grown on the rich medium. This was consistent with the 
finding that alkaline phosphatase formation in $E$. coli strain ML was repressed (Torriani, 1960) by orthophosphate, a component in the sM agar.

In cell-free extracts prepared from the amoebae immediately after removal from the complex medium, as well as after washing and after starvation for $3 \mathrm{hr}$ on the plain agar, the alkaline phosphatase activities were 11,13 and $19 \mathrm{~m} \mu \mathrm{m} / \mathrm{min} . / \mathrm{mg}$. protein, respectively. In a separate experiment, the amoebae were grown on dead

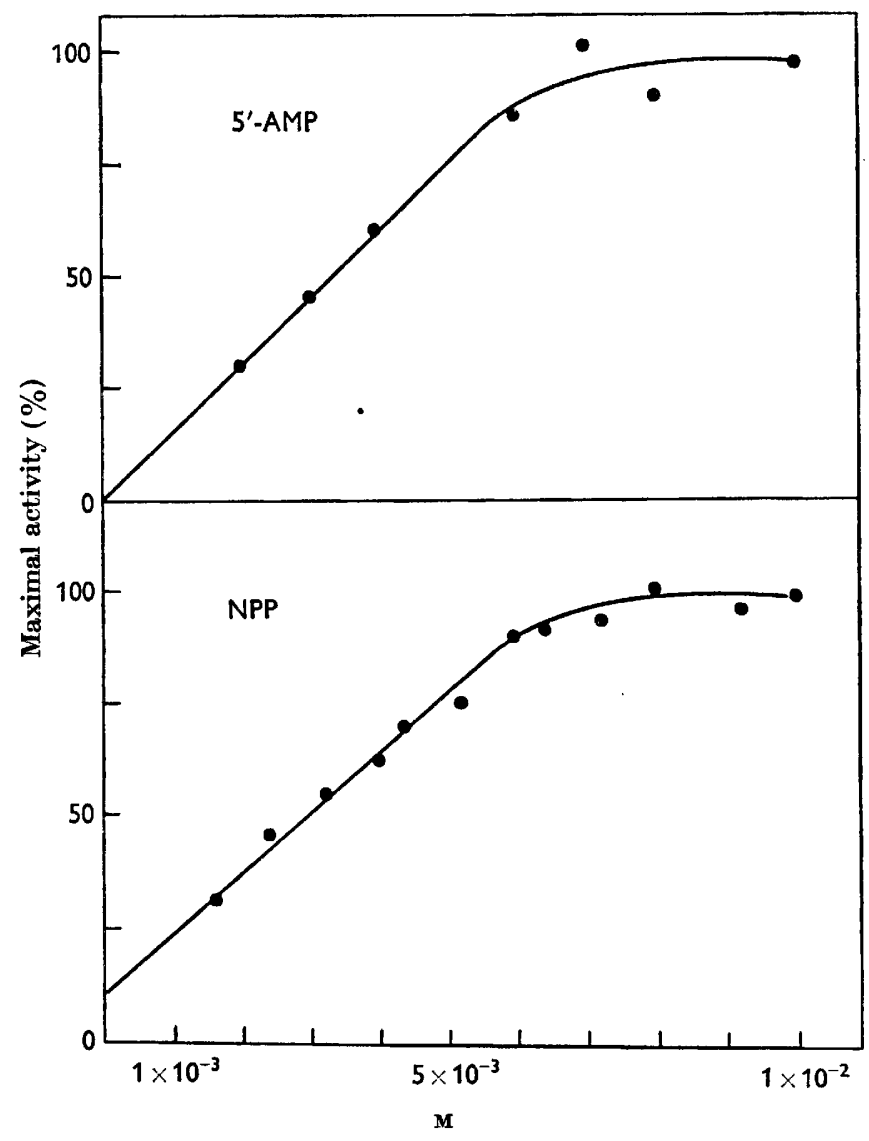

Fig. 3. Phosphatase activity against NPP and $5^{\prime}$-AMP (top) as a function of substrate concentration (same abscissa for each substrate). The activities (expressed as per cent of maximal activity) were assayed in $0.5 \mathrm{M}$-tris without $\mathrm{MgCl}_{2}$ (NPP) and in $0.05 \mathrm{M}$-tris, $0 \cdot 02 \mathrm{M}-\mathrm{MgCl}_{2}$ (AMP).

Escherichia coli. No control with living bacteria was possible because of the lower growth rate on the dead organism (Raper, 1951). The phosphatase activity obtained was $18 \mathrm{~m} \mu \mathrm{M} / \mathrm{min}$./mg. protein, i.e. of the same magnitude as observed for amoebae grown on live bacteria. It is therefore concluded that the alkaline phosphatase activity measured in the amoeba extracts was derived from Dictyostelium discoideum.

Remnant bacteria, possibly de-repressed on the plain agar, did not contribute significantly to the alkaline phosphatase activity in the sorocarp extracts since spores separated from stalks, debris and bacteria gave an extract higher in specific 
activity than the complete sorocarps. Apparently the stalks contained relatively little of the enzyme. All experiments were performed with cell-free extracts. However, the enzyme-specific activity against NPP was the same whether the homogenate or the extract was used.

Stability. Storage of the cell-free extracts at $+4^{\circ}$ resulted in loss of activity, especially in those prepared at the early stages of development (Table 1). However,

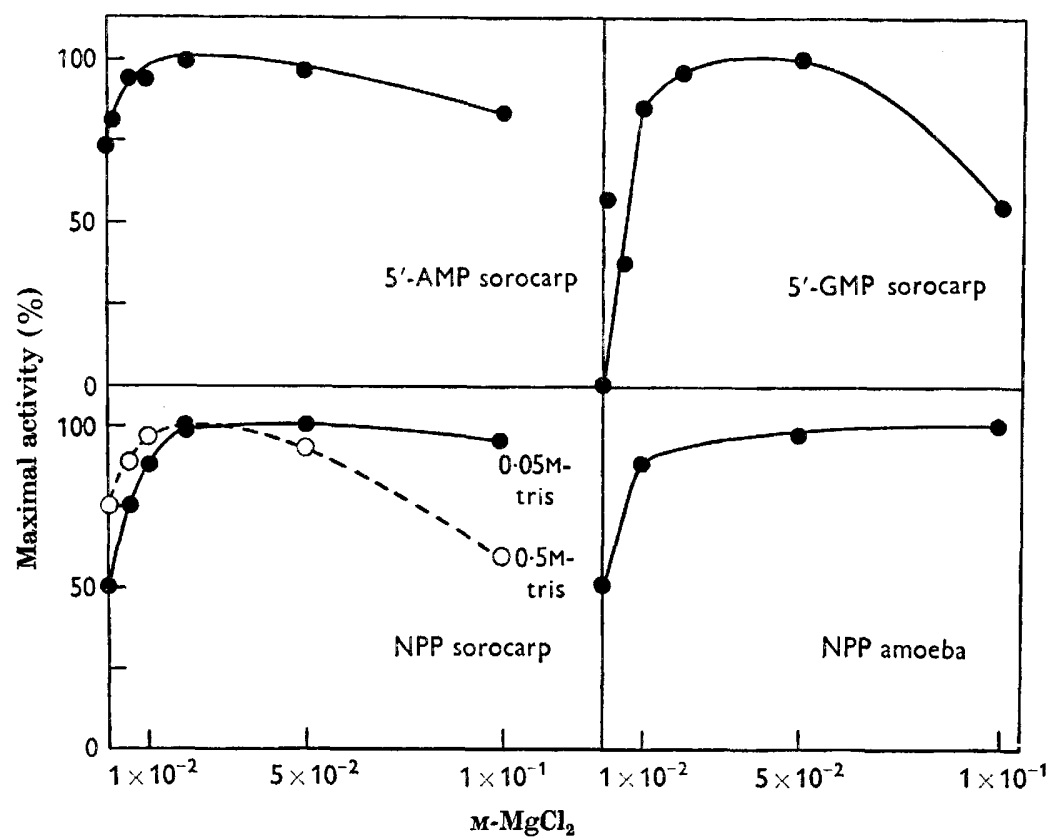

Fig. 4. $\mathrm{Mg}^{2+}$ activation of phosphatase activity against NPP (bottom), $\mathbf{5}^{\prime}$-AMP and 5'-GMP (top). The tris buffer concentration was $0.05 \mathrm{M}$. The activity of the sorocarp enzyme against NPP was also assayed in $0.5 \mathrm{M}$-tris. The activities are expressed as per cent of maximal activity.

Table 1. Activity with time of undiluted extracts

\begin{tabular}{lcccc} 
& \multicolumn{4}{c}{ Specific enzyme activities } \\
\cline { 2 - 5 } \multicolumn{1}{c}{ Stage } & Fresh & 1 day & 2 days & 8 days \\
Amoeba & 10 & 4 & 2 & 1 \\
Preculmination & 14 & 7 & 3 & 4 \\
Sorocarp & 60 & 63 & 37 & 31
\end{tabular}

The concentrated extracts were stored at $+4^{\circ}$ and assayed without dilution in $0.5 \mathrm{M}$-tris without $\mathrm{MgCl}_{2}$. Specific enzyme activity is defined in Methods.

when the extracts were diluted immediately by a factor of 100, i.e. to a concentration of about $0.1 \mathrm{mg}$. protein $/ \mathrm{ml}$. and stored as such at $+4^{\circ}$, no decrease in activity appeared in $48 \mathrm{hr}$ (Table 2). There was, on the contrary, a pronounced increase in alkaline phosphatase activity during the first day, especially in the sorocarp extract (see below). Because of this release of enzyme activity and the stability of the enzyme thereafter, the phosphatase activities were always assayed after storage of 
the diluted extracts at $+4^{\circ}$ for 20-24 hr. Dialysis of the diluted extracts did not increase the alkaline phosphatase activities beyond what was obtained through dilution only.

The crude extracts tolerated a temperature of $50^{\circ}$ for 5 min.; prolonged treatment (30 min.) inactivated the alkaline phosphatase. At $80^{\circ}$ all activity was lost within $1 \mathrm{~min}$. both at the sorocarp and the amoeba stage. Because of the undefined conditions in the extracts, no further experiments on heat stability were performed.

Table 2. Effect of dilution and stability of diluted enzyme

\begin{tabular}{lcccc} 
& \multicolumn{4}{c}{ Specific enzyme activities } \\
Stage & $\begin{array}{c}\text { Undiluted } \\
\text { extract }\end{array}$ & $0 \mathrm{hr} *$ & $20 \mathrm{hr} *$ & $48 \mathrm{hr}^{*}$ \\
Amoeba & 13 & 16 & 18 & 18 \\
Preculmination & 28 & 32 & 38 & 37 \\
Sorocarp & 52 & 69 & 95 & 95
\end{tabular}

The fresh extracts were diluted to a concentration of $c a .0 \cdot 1 \mathrm{mg}$. protein $/ \mathrm{ml}$. and stored at $+4^{\circ}$. The activities were measured in $0.5 \mathrm{M}$-tris without $\mathrm{MgCl}_{2}$.

* Hours after initial dilution.

\section{Table 3. Relative substrate specificities in an extract of sorocarps}

\begin{tabular}{|c|c|c|c|c|c|}
\hline & $0.02 \mathrm{M}-\mathrm{MgCl}_{2}$ & No $\mathrm{MgCl}_{2}$ & & $0.02 \mathrm{M}-\mathrm{MgCl}_{2}$ & No $\mathrm{MgCl}_{2}$ \\
\hline NPP & 100 & 52 & 5'-UMP & 1 & - \\
\hline $5^{\prime}$-AMP & 41 & 22 & $5^{\prime}-$ TMP & 5 & - \\
\hline $5^{\prime}$-GMP & 160 & o & 5'-IMP & $\mathbf{1}$ & - \\
\hline ATP & 64 & 33 & $\mathbf{3}^{\prime}$-AMP & 8 & 一 \\
\hline ADP & 5 & 0 & TPN & 5 & - \\
\hline GTP & 7 & o & G6P & 5 & - \\
\hline GDP & 77 & 0 & G1P & $\mathbf{5}$ & - \\
\hline UTP & 45 & $\mathbf{0}$ & FDP & 0 & - \\
\hline UDP & 6 & $\mathbf{0}$ & $\beta \mathbf{G P}$ & 5 & - \\
\hline $5^{\prime}-\mathrm{CMP}$ & 1 & 一 & & & \\
\hline
\end{tabular}

The activities were measured at $\mathrm{pH} 9.0$ in $0.05 \mathrm{M}$-tris, at $0.01 \mathrm{~m}$ substrate concentration.

\section{Substrate specificity}

A large number of phosphate esters were tested as substrates for the alkaline phosphatase at the sorocarp and amoeba stages (Tables 3, 4). The tables show that, for the compounds tried at both stages, the substrate specificity was the same in the amoeba and sorocarp extracts. Since the pH optimum (Fig. 2) and the $\mathrm{Mg}^{2+}$ activation (Fig. 4) also were the same at both stages, it seemed probable that the amoeba and sorocarp alkaline phosphatases were identical.

$\beta$ GP, used by Bonner et al. (1955) and by Krivanek (1956) was a poor substrate for the enzyme. It required prolonged incubation times (1-3 hr) and higher substrate concentration than did NPP. Although the results for $\beta$ GP are therefore difficult to interpret, the specific activity did increase from amoeba to sorocarp in the experiments, thus resembling the activity pattern against NPP.

G6P, G1P and FDP were only very slightly hydrolysed at $\mathrm{pH} \mathrm{9.0,} \mathrm{if} \mathrm{at} \mathrm{all.} \mathrm{Of}$ these compounds, at least G6P and FDP served as substrates for the acid phos- 
phatase, which was not activated by $\mathrm{Mg}^{2+}$. The low activities against these three phosphate esters obtained at $\mathrm{pH} 9.0$ were probably due to this latter enzyme.

Of the $5^{\prime}$-nucleotides listed in Table 3 , only $5^{\prime}$-AMP and $5^{\prime}$-GMP were readily hydrolysed at $\mathrm{pH} \mathrm{9 \cdot 0}$; GMP, however, was only attacked in the presence of $\mathrm{Mg}^{2+}$.

With NPP and 5'-AMP there was a 6 -fold increase in enzyme concentration during differentiation (Table 5). Hence the ratio between the specific activities in AMP and NPP was constant during development. The specific activity on 5'-GMP was entirely different: it was about the same at all stages. The ratio 5'-GMP:NPP was therefore highest at the amoeba and lowest at the sorocarp stage. Together

Table 4. Relative substrate specificities in an extract of amoebae

\begin{tabular}{lr} 
NPP & 100 \\
5'-AMP $^{\prime}$-AMP & 42 \\
$5^{\prime}$-UMP & 0 \\
5'-TMP $^{\prime}$-TMP & 0 \\
$5^{\prime}$-IMP & 0 \\
3'-AMP $^{\prime}$ GP & 0 \\
G6PP & 0 \\
FDP & 0 \\
BGP & 9 \\
\hline
\end{tabular}

The activities were assayed at $\mathrm{pH} 9.0$ in $0.05 \mathrm{M}$-tris, $0.02 \mathrm{M}$ with respect to $\mathrm{MgCl}_{2}$, at $0.01 \mathrm{M}$ substrate concentration.

Table 5. Phosphatase specific activities on NPP, $5^{\prime}-A M P$ and $5^{\prime}$-GMP at four stages of development

\begin{tabular}{|c|c|c|c|c|c|}
\hline & & \multicolumn{2}{|c|}{ Ratio 5'-AMP } & & Ratio 5'-GMP \\
\hline Stage & NPP & $\mathbf{5}^{\prime}$-AMP & NPP & $5^{\prime}-\mathbf{G M P}$ & $\overline{\mathbf{N P P}}$ \\
\hline Amoeba & 29 & 11 & $0 \cdot 38$ & 187 & $6 \cdot 43$ \\
\hline Preculmination & 56 & 23 & $0 \cdot 41$ & 178 & $3 \cdot 17$ \\
\hline Culmination & 76 & 29 & $0 \cdot 38$ & 157 & $2 \cdot 06$ \\
\hline Sorocarp & 157 & 66 & 0.42 & 176 & $1 \cdot 12$ \\
\hline
\end{tabular}

The activities were measured at $\mathrm{pH} \mathrm{9.0} \mathrm{in} 0.05 \mathrm{M}$-tris, $0.03 \mathrm{M}$ with respect to $\mathrm{MgCl}_{2}$, at $0.01 \mathrm{M}$ substrate concentration.

Table 6. Phosphate specific activities on NPP, $5^{\prime}-A M P$ and $5^{\prime}-d A M P$ at two stages of development

$\begin{array}{lccc}\text { Stage } & \text { NPP } & 5^{\prime} \text {-AMP } & 5^{\prime} \text {-dAMP } \\ \text { Amoeba } & 24 & 12 & 11 \\ \text { Sorocarp } & 168 & 79 & 79\end{array}$

The extracts were assayed in the presence of $0.05 \mathrm{M}$-tris and $0.02 \mathrm{M}-\mathrm{MgCl}_{2}$, at $0.01 \mathrm{M}$ substrate concentration.

with the absolute $\mathrm{Mg}^{2+}$ requirement for phosphatase activity against GMP, the enzyme activity pattern during development provided strong evidence that $5^{\prime}$-GMP was hydrolysed by an enzyme other than the alkaline phosphatase. This conclusion is supported further by the fact that the hydrolysis of GMP has a different $\mathrm{pH}$ optimum than that of NPP (Fig. 2).

The phosphatase activity was the same whether $5^{\prime}$-AMP or 5'-dAMP was used 
as substrate at pH 9. For both these compounds, as well as for NPP, there was a 7 -fold increase in enzyme concentration during differentiation (Table 6). The hydrolysis of $5^{\prime}$-dAMP showed the same $\mathrm{Mg}^{2+}$ activation as that of $\mathbf{5}^{\prime}$-AMP and NPP. Both AMP and AAMP must thus be considered as probable substrates for the alkaline phosphatase.

Of the di- and trinucleotides studied (Table 3), phosphatase activity was obtained against GDP, ATP and UTP. GDP and UTP were, however, only hydrolysed in the presence of $\mathrm{Mg}^{2+}$. They must therefore be excluded as substrates for the alkaline phosphatase.

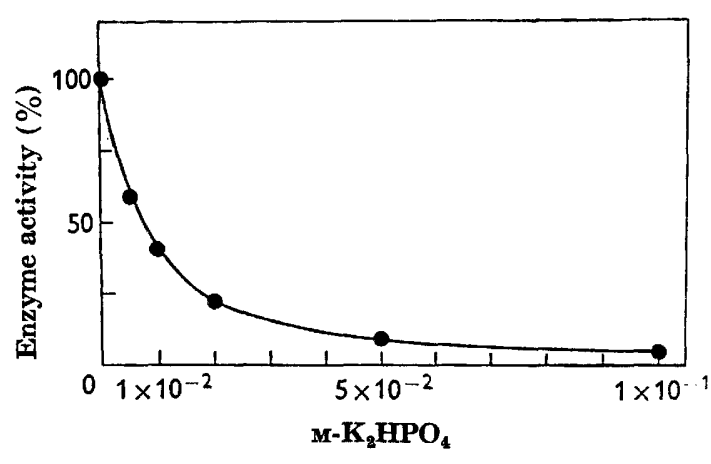

Fig. 5

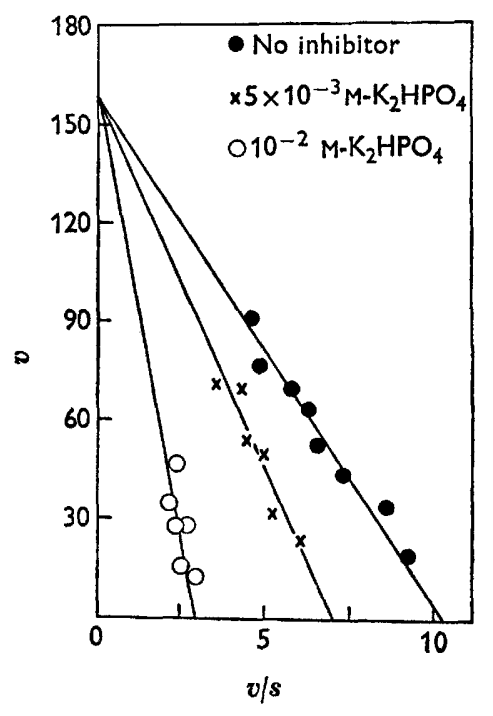

Fig. 6

Fig. 5. Pi inhibition of alkaline phosphatase activity in a dialysed sorocarp extract. The activities were assayed in $0.5 \mathrm{M}$-tris without $\mathrm{MgCl}_{2}$ and expressed as per cent of the activity obtained in the absence of Pi. Enzyme activity was determined by nitrophenol formation.

Fig. 6. Alkaline phosphatase activity against NPP in a dialysed sorocarp extract assayed with and without added $\mathrm{K}_{2} \mathrm{HPO}_{4}$. The activities are plotted as $v$ versus $v / s$ ( $v$ in $\mathrm{m} \mu \mathrm{M} / \mathrm{min}$./mg. protein; $s$ in $\mathrm{mm})$. The activities were measured in $0.5 \mathrm{M}$-tris without $\mathrm{MgCl}_{2}$.

Table 7. Phosphatase specific activities of a fresh and aged dialysed extract of sorocarps on NPP, $5^{\prime}-A M P$ and $A T P$

$\begin{array}{lccc} & \text { Fresh } & \text { Aged } & \begin{array}{c}\text { Residual } \\ \text { activity (\%) }\end{array} \\ \text { NPP } & 138 & 131 & 95 \\ \text { 5'-AMP } & \mathbf{5 5} & \mathbf{5 5} & 100 \\ \text { ATP } & \mathbf{3 7} & \mathbf{9} & \mathbf{2 4}\end{array}$

The activities were assayed in the presence of $0.05 \mathrm{M}$-tris, and $0.02 \mathrm{M}-\mathrm{MgCl}_{2}$. The diluted and dialysed extract was aged at $-20^{\circ}$ for 3 days before re-assaying.

ATP was hydrolysed even in the absence of $\mathrm{Mg}^{2+}$ (Table 3). The activity varied immensely, however, between the experiments. As shown in Table 7, the enzyme attacking ATP is very unstable, and it is for this reason not identical with the alkaline phosphatase. 
Sodium pyrophosphate, $\mathbf{P P i}$, was hydrolysed at alkaline $\mathrm{pH}$ values with a sharp optimum at $\mathrm{pH} \mathrm{8.8.} \mathrm{The} \mathrm{reaction} \mathrm{was} \mathrm{completely} \mathrm{Mg}^{2+}$ dependent and required a $\mathrm{Mg}: \mathrm{PPi}$ ratio of unity for optimal activity. The specific activity hardly changed during differentiation. (Under optimal conditions the values 1020, 770, 1050 and $970 \mathrm{~m} \mu \mathrm{M} / \mathrm{min}$./mg. protein were obtained for the amoeba, pre-culmination, culmination and sorocarp stages, respectively.) Hence the pyrophosphatase and the alkaline phosphatase must be two different enzymes.

Of all naturally occurring compounds studied, only $5^{\prime}$-AMP and $5^{\prime}$-dAMP were possible substrates for the alkaline phosphatase.

With respect to enzyme pattern during differentiation (Table 5) stability (Table 7), pH optimum (Fig. 2), effect of substrate concentration (Fig. 3), and $\mathrm{Mg}^{2+}$ activation (Fig. 4) the characteristics for phosphatase activity against NPP and $5^{\prime}$-AMP were the same. This suggests the same enzyme. It is hence concluded that $5^{\prime}$-AMP and $5^{\prime}$-dAMP as well as NPP are hydrolysed by the alkaline phosphatase in Dictyostelium discoideum.

\section{Inhibition by orthophosphate (Pi)}

With NPP or with $5^{\prime}$-AMP as substrate the alkaline phosphatase in Dictyostelium was inhibited by its end product, orthophosphate. The inhibition at $\mathrm{pH} 9$ was about $50 \%$ at a phosphate concentration of $0.007 \mathrm{M}$ and almost complete in 0.05 0.1 $\mathrm{M}^{-} \mathrm{K}_{2} \mathrm{HPO}_{4}$ (Fig. 5). Similar curves were obtained for both amoeba and sorocarp extracts.

In Fig. 6 the enzyme activities with and without phosphate are plotted as $v$ versus $v / s$ according to the formula

$$
v=V_{\max }-v / s\left(1+\frac{I}{K_{I}}\right) K_{m}
$$

(Eadie, 1952). The increased slopes in the presence of inhibitor and the fact that the straight lines all have the same intercept $\left(V_{\max }\right)$ show that orthophosphate was a competitive inhibitor of alkaline phosphatase in vitro.

\section{Intracellular orthophosphate}

Because of this end-product inhibition of alkaline phosphatase in vitro, the intracellular orthophosphate $(\mathbf{P i})$ concentration was determined at various stages of development. The first column in Table 8 shows that the phosphateconcentration increased about 20-fold during the development from amoebae to spores. Calculated for the whole sorocarp the increase was less; the stalks contribute significantly to the packed cell volume but probably not to the phosphate determinations. The main increase in intracellular phosphate occurred at the late culmination and young sorocarp stages. The extent to which the various phosphate concentrations inhibited alkaline phosphatase activity in vitro (Fig. 5) is shown in the second column of Table 8.

\section{Phosphate release and phosphate inhibition in vitro}

As shown in Table 8 orthophosphate (Pi) was present in the spores in a concentration high enough to inhibit the alkaline phosphatase by more than $90 \%$. The Pi concentration in the amoebae would cause only a $25 \%$ inhibition.

In the concentrated fresh extracts, the enzyme must also have been inhibited to 
some extent. A determination of the $\mathrm{Pi}$ contents gave the values $10^{-3} \mathrm{M}$ for the amoeba and $3 \times 10^{-3} \mathrm{M}$ for the sorocarp extract, corresponding to 10 and $25 \%$ inhibition of the enzyme (Fig. 5). A 100-fold dilution of the extracts decreased the $\mathrm{Pi}$ values to $10^{-5}$ and $3 \times 10^{-5} \mathrm{M}$ respectively, at which concentrations there is no $\mathrm{Pi}$ inhibition (Fig. 5). However, maximal activity was not obtained immediately after dilution and the increase in the sorocarp extract during the first $20 \mathrm{hr}$ was considerably higher than in the extracts from the early stages (Table 2). In an experiment involving two sorocarp extracts, one was prepared in $0.05 \mathrm{M}$ phosphate

\section{Table 8. Intracellular Pi molarity* during development}

\begin{tabular}{lcc}
\multicolumn{1}{c}{ Stage } & & $\begin{array}{c}\text { Inhibition in vitro } \\
\text { of alkaline } \\
\text { phosphatase (\%) }\end{array}$ \\
Amoeba & Molarity Pi & 25 \\
Pre-culmination & $\mathbf{0 . 0 0 3}$ & $\mathbf{2 5}$ \\
Culmination & $\mathbf{0 . 0 0 3}$ & $\mathbf{4 5}$ \\
Very young sorocarp (including stalks) $\dagger$ & $\mathbf{0 . 0 0 6}$ & 67 \\
1 day soroacarp (with stalks) $\dagger$ & $\mathbf{0 . 0 1 4}$ & $\mathbf{7 8}$ \\
Spores & $\mathbf{0 . 0 2 0}$ & $\mathbf{9 3}$
\end{tabular}

* Expressed in terms of packed cell volume.

$\dagger$ Stalks, present in both these preparations, contribute significantly to the packed cell volumes but not to the phosphate contents of the extracts.

buffer (the approximate $\mathrm{Pi}$ concentration in the spores) and the other, as a control, in $0.01 \mathrm{M}$-tris, both at $\mathrm{pH} \mathbf{7 \cdot 2}$. The fresh extracts were diluted 100 -fold in tris. This brought the Pi concentrations below inhibiting values (Fig. 5) in both extracts. Most of the $90 \%$ inhibition caused by the $0.05 \mathrm{M}$-phosphate was released immediately after dilution. The specific activity was $74 \mathrm{~m} \mu \mathrm{m} / \mathrm{min} . / \mathrm{mg}$. protein compared to 85 in the control. Maximal activity (105 $\mathrm{m} \mu \mathrm{M} / \mathrm{min} . / \mathrm{mg}$. protein) was obtained in both diluted extracts within $20 \mathrm{hr}$. When the phosphate-containing thick extract was preincubated $24 \mathrm{hr}$ before dilution, the specific activity immediately after dilution was low, $29 \mathrm{~m} \mu \mathrm{M} / \mathrm{min}$./mg. protein, suggesting a binding of phosphate to the enzyme. The final activity, after $20 \mathrm{hr}$, however, was the same as in the not pre-incubated, 100-fold diluted extracts. This slow recovery from $\mathrm{Pi}$ inhibition in the preincubated extract may explain the slow increase in activity obtained during the first $20 \mathrm{hr}$ in the diluted ordinary extracts (Table 2). This might then be due to release from bound phosphate (Schwartz, 1963).

Table 1 showed that the phosphatase activity decreased with time in the concentrated extracts. This decrease was about $80 \%$ during the first 2 days at the amoeba stage and $40-50 \%$ at the sorocarp stage. During this time the phosphate content increased to about $5 \times 10^{-3} \mathrm{M}$, both in the amoeba and sorocarp extracts. This concentration inhibited the alkaline phosphatase in vitro to $40 \%$ (Fig. 5), while the $\mathrm{Pi}$ concentrations in the fresh extracts corresponded to 10 and $25 \%$ inhibition (see above). Hence, only part of the decrease in enzyme activity could be explained through phosphate inhibition. The enzyme was possibly inhibited also by some other phosphate compound(s). Apparently the decrease was not due to instability of the enzyme: a 100-fold dilution of the aged concentrated extracts and storage of the dilutions at $+4^{\circ}$ for $20 \mathrm{hr}$ did not only restore the enzyme activities 
but increased them, at the early developmental stages, above the values obtained in the diluted fresh extracts. The same increase occurred in preparations kept at $-20^{\circ}$ for $20 \mathrm{hr}$ before dilution. The effect was about 2 -fold at the amoeba stage and very low at the sorocarp stage (Fig. 7). The nature of this increase was not studied. It might, however, have involved an activation or release of preformed enzyme protein. Increase in alkaline phosphatase activity in vitro has been reported for Bacillus subtilis (Whiteley \& Oishi, 1963).

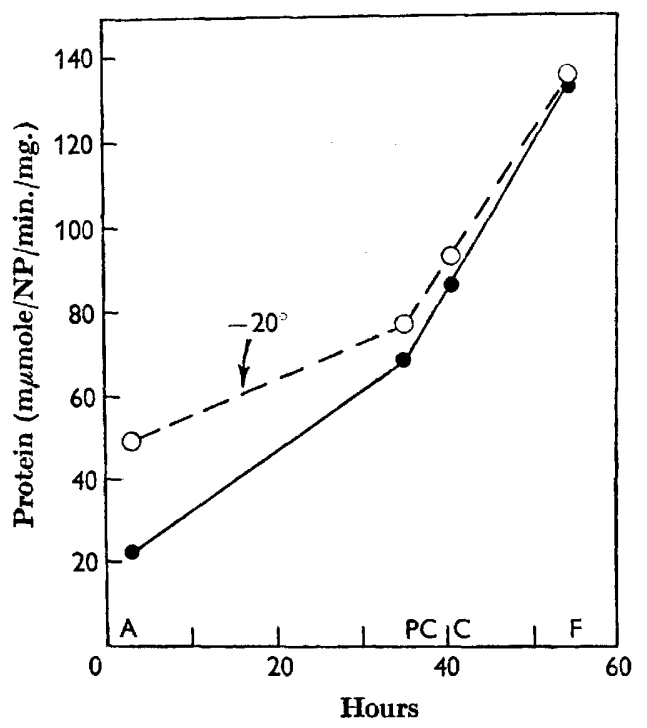

Fig. 7

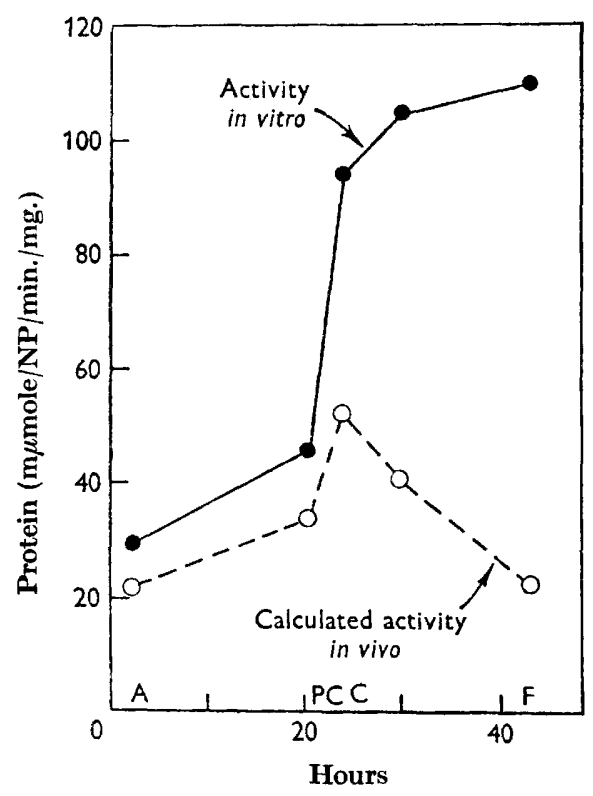

Fig. 8

Fig. 7. Alkaline phosphatase activity in vitro during differentiation. The lower curve represents the activity in the fresh extracts. The upper curve shows the release of enzyme activity obtained through freezing. The activities were assayed in $0.5 \mathrm{M}$-tris without $\mathrm{MgCl}_{2}$. The symbols along the abscissa in this and subsequent graphs refer to amoeba (A), pre-culmination (PC), culmination (C), and sorocarp (F) stages.

Fig. 8. Specific phosphatase activity against NPP during development. The calculated activity in vivo is based on the amount of orthophosphate present in the cells at the various stages of differentiation. The extracts were assayed in $0.05 \mathrm{M}$-tris, and $0.1 \mathrm{M}$ $\mathrm{MgCl}_{2}$.

\section{Phosphatase activity in vitro and in vivo}

Figure 8 shows both the alkaline phosphatase activities in vitro and the predicted enzyme activities in vivo based on the intracellular phosphate molarities and assuming that the inhibitor was available to the enzyme. The data indicate an increase during differentiation in enzyme concentration but suggest that the inhibition of the enzyme in vivo resulted in highest activity during culmination.

\section{Alkaline phosphatase in cells differentiating in the presence of exogenous metabolites}

In all the previous experiments the slime mould was differentiating on plain $2 \%$ agar in the absence of any exogenous nutrients. When orthophosphate or 
glucose was present in the agar, the rate of differentiation was increased. The optimal stimulating concentrations were $0.01 \mathrm{M}$ with respect to $\mathrm{Pi}$ and $0.05 \mathrm{M}$ for glucose (Krichevsky \& Wright, 1963). In the presence of $0.01 \mathrm{M} \mathrm{Pi}$ the intracellular Pi values were higher than when the slime mould was differentiating on plain agar, but only early in development. The high $\mathrm{Pi}$ concentrations in the sorocarps were not further increased (Table 9). On plain agar, the intracellular glucose content was highest during pre-culmination and culmination (Wright, Brühmüller \& Ward, 1964). Although direct determinations were not made, it is known that exogenous glucose does enter the cells during differentiation, since it stimulates the rate of development and respiration and also affects the pathways of hexose metabolism (Wright et al. 1964).

\section{Table 9. $P$ i molarity* in cells differentiating on plain agar and on agar $0.01 \mathrm{M}$ with respect to $\boldsymbol{P i}$}

\begin{tabular}{lcc}
\multicolumn{1}{c}{ Stage } & $\overbrace{\text { Plain agar }}$ Molarity Pi* & $0.01 \mathrm{M} \mathrm{Pi}$ agar \\
Aggregation & 0.002 & 0.005 \\
Pseudoplasmodium & 0.002 & 0.005 \\
Culmination & 0.005 & - \\
Very young sorocarp $\dagger$ & - & 0.011 \\
1 day sorocarp & 0.013 & 0.013 \\
2 day sorocarp & 0.021 & 0.018 \\
* Expressed in terms of packed cell volume. & \\
† The stalks were included in all the sorocarp preparations.
\end{tabular}

Figure 9 shows the alkaline phosphatase activity in vitro from cells differentiating on plain agar, and on agar $0.01 \mathrm{~m}$ with respect to $\mathrm{Pi}$ or $0.05 \mathrm{~m}$ with respect to glucose. The enzyme was assayed, as always, under conditions of no Pi inhibition. In the presence of exogenous $\mathrm{Pi}$ or glucose, the phosphatase values did not increase after culmination, while in the control the enzyme concentration was maximal in the sorocarps. Early in development there was no negative effect of either $\mathbf{P i}$ or glucose. On the contrary, the phosphatase concentration was higher in the cells on $\mathrm{Pi}$ agar. This is most likely due to the fact that phosphate is speeding up the rate of development.

No attempts were made to study the synthesis of the alkaline phosphatase protein. However, the data in Fig. 9 suggest that the enzyme was repressed, but only in the sorocarps, in the presence of glucose or $\mathrm{Pi}$. This effect of $\mathrm{Pi}$, and probably also of glucose, appeared to be a delayed phenomenon, since the alkaline phosphatase levels were not affected in the early stages, though the intracellular Pi concentration was increased when the compound was present in the agar (Table 9). This was more strikingly demonstrated when $0 \cdot 1 \mathrm{M} \mathbf{P i}$ was used. In an experiment with this concentration, the $\mathrm{Pi}$ inside the cells was $0.028 \mathrm{M}$ in the young pre-culmination stage as compared to $0.002 \mathrm{M}$ in the somewhat slower control (still pseudoplasmodia). There was thus a 14-fold increase in intracellular Pi, yet the alkaline phosphatase concentration was not affected in the early stages of development.

The SM medium contained, in addition to potassium phosphate $(0.016 \mathrm{M})$ and glucose $(0.05 \mathrm{M})$, peptone and yeast extract. Excluding the yeast extract, this was 
the substrate used in the investigations by Bonner et al. (1955), Krivanek (1956) and Krivanek \& Krivanek (1958). On this medium the effect on the enzyme was much more pronounced than in the presence of $\mathrm{Pi}$ or glucose alone; the phosphatase concentration decreased drastically in the sorocarps (Fig. 10). When concentrated extracts were used (as in the experiments by Krivanek, 1956), the phosphatase values obtained for the sorocarps were still lower, due to phosphate inhibition in the extracts.

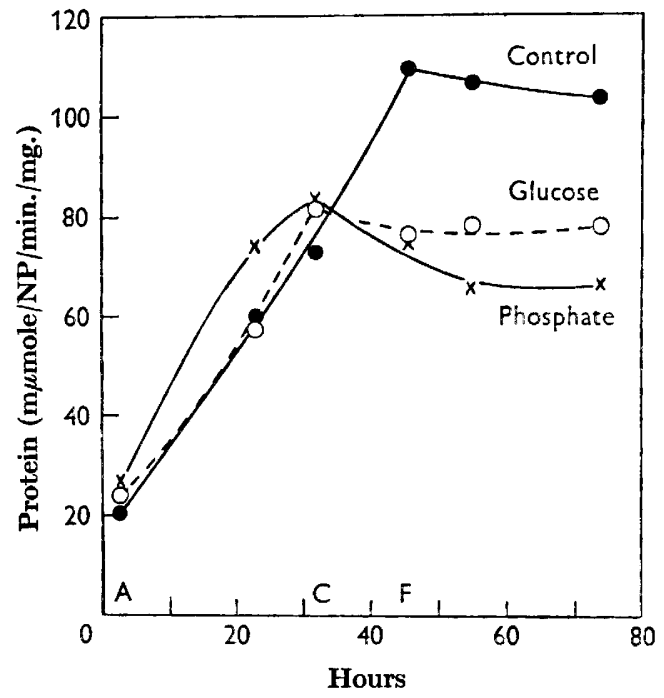

Fig. 9

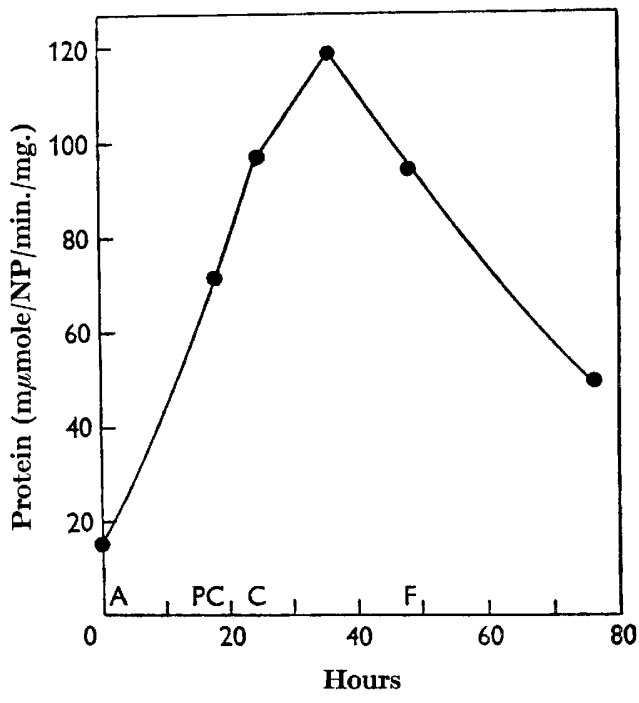

Fig. 10

Fig. 9. Specific phosphatase activity against NPP during development for cells differentiating on plain $2 \%$ agar without any supplements (control), on $2 \%$ agar, 0.01 M-potassium phosphate and on $2 \%$ agar, 0.05 M-glucose. The activities of the diluted, dialysed extracts were assayed in $0.05 \mathrm{M}$-tris, $0.02 \mathrm{M}-\mathrm{MgCl}_{2}$.

Fig. 10. Specific phosphatase activity against NPP during development for cells differentiating on the SM medium in the presence of residual food bacteria. The diluted, dialysed extracts were assayed in $0.05 \mathrm{M}$-tris, $0.02 \mathrm{M}-\mathrm{MgCl}_{2}$.

Table 10. Specific enzyme activities in extracts from sorocarps formed in the presence of exogenous adenosine and deoxyadenosine

\begin{tabular}{|c|c|c|c|c|c|}
\hline \multirow[b]{3}{*}{ Stage } & \multicolumn{5}{|c|}{ Specific enzyme activities } \\
\hline & \multirow[b]{2}{*}{ Control } & \multicolumn{2}{|c|}{ Adenosine } & \multicolumn{2}{|c|}{ Deoxyadenosine } \\
\hline & & $5 \times 10^{-4} M$ & $5 \times 10^{-3} \mathrm{M}$ & $5 \times 10^{-4} M$ & $5 \times 10^{-3} \mathrm{M}$ \\
\hline Very young sorocarp & 184 & 174 & $\begin{array}{l}120 \\
308\end{array}$ & $\begin{array}{l}194 \\
310\end{array}$ & 200 \\
\hline 2-day sorocarp & 180 & 300 & 308 & 310 & 400 \\
\hline
\end{tabular}

The diluted, dialysed extracts were assayed in $0.05 \mathrm{M}$-tris, $0.02 \mathrm{M}$ with respect to $\mathrm{MgCl}_{2}$.

The nucleosides adenosine and deoxyadenosine, end products of the $5^{\prime}$-nucleotidase reaction, were somewhat inhibitory to the rate of slime mould development. The inhibition in the presence of adenosine was quite obvious at $5 \times 10^{-3} \mathrm{M}$. As shown in Fig. 11, both compounds increased the specific enzyme activities in the 
sorocarps and they seemed thus to induce alkaline phosphatase formation in Dictyostelium. The data in Table 10 suggest that deoxyadenosine had a stronger effect than adenosine. All extracts were assayed after dilution and dialysis, i.e. in the absence of any removable inhibitor.

Figure 12, bottom, shows the Pi concentrations in cells differentiating on plain agar and on agar $5 \times 10^{-3} \mathrm{M}$ in respect to adenosine. Early in development the intracellular Pi molarities were the same in both cases, but during sorocarp formation and in the sorocarps the $\mathbf{P i}$ concentration was considerably lower in the presence of

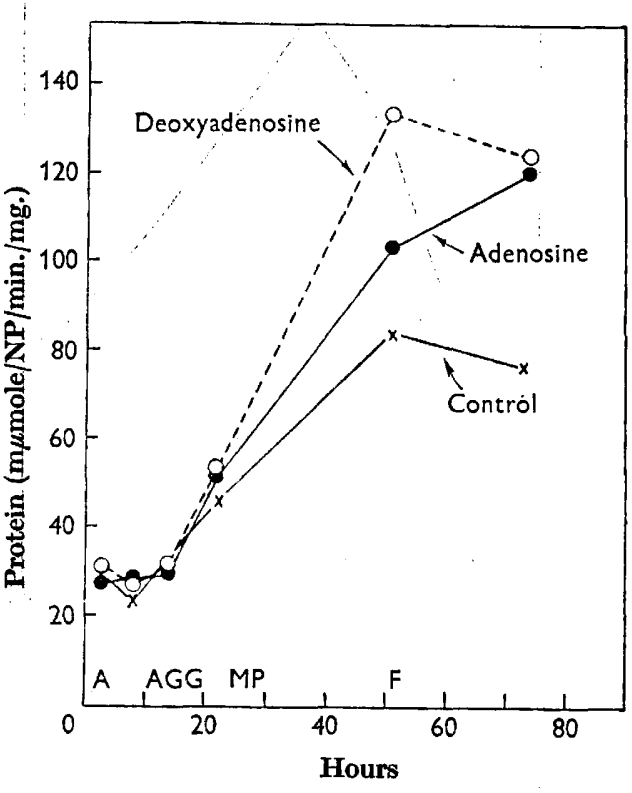

Fig. 11

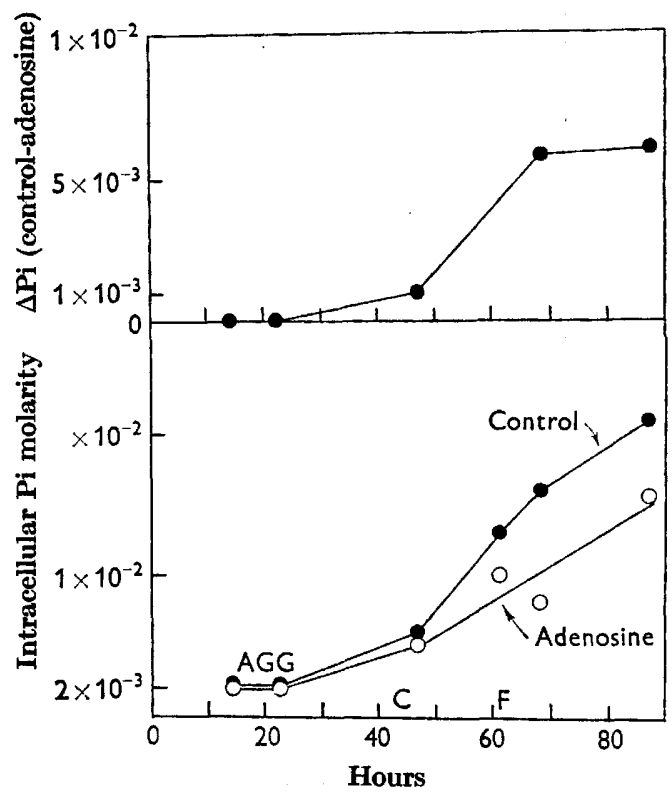

Fig. 12

Fig. 11. Specific phosphatase activity against NPP for cells differentiating on plain $2 \%$ agar (control) or agar $5 \times 10^{-3} \mathrm{M}$ in adenosine and deoxyadenosine respectively. The diluted dialysed extracts were assayed in $0.05 \mathrm{M}$-tris, $0.02 \mathrm{M}-\mathrm{MgCl}_{2}$. The symbols indicate amoeba (A), aggregation (AGG), migrating pseudoplasmodium (MP) and sorocarp (F) stages.

Fig. 12. Lower graph: Intracellular Pi molarity (expressed in terms of packed cell volume) during development on $2 \%$ plain agar (control) and on agar $5 \times 10^{-8} \mathrm{M}$-adenosine. Top graph: Plot of the calculated difference in intracellular Pi molarities between cells on plain and adenosine agar during development.

exogenous adenosine. The upper part of Fig. 12 represents a plot of the calculated difference in intracellular $\mathrm{Pi}$ between cells on plain and on adenosine agar. The resulting curve rises during sorocarp formation and in the young sorocarps, the stage at which the stimulation of alkaline phosphatase levels occurred in the presence of adenosine.

\section{DISCUSSION}

Of naturally occurring compounds the alkaline phosphatase of Dictyostelium discoideum, routinely assayed with NPP, hydrolyses AMP and dAMP. It is in this respect completely different from the unspecific alkaline phosphatase of Escherichia 
coli which hydrolyses mononucleotides and hexosephosphates (Torriani, 1960; Garen \& Levinthal, 1960) and such compounds as ATP, ADP and PPi (Heppel, Harkness \& Hilmoe, 1962). The specific 5'-nucleotidases studied usually attack several mononucleotides but not NPP (Reis, 1951; Heppel \& Hilmoe, 1951; Sulkowski, Björk \& Laskowski, 1963).

The in vitro activity pattern obtained on plain agar for $\beta \mathrm{GP}$, a very poor substrate for the Dictyostelium enzyme, resembled that for NPP. In the presence of nutrients, the activity pattern for NPP (Fig. 10) was the same as that shown for $\beta$ GP (Bonner et al. 1955; Krivanek, 1956). A comparison between the Krivanek's data for alkaline phosphatase (1956) and for $5^{\prime}$-nucleotidase (1958) shows identical distribution of the enzymes. We consider it most probable that these enzymes are one and the same, and that the enzyme studied by us with NPP and $5^{\prime}$-AMP as substrates is identical with the alkaline phosphatase described by Bonner et al. (1955) and by Krivanek (1956).

The alkaline phosphatase in Dictyostelium is inhibited by orthophosphate. Data (Fig. 9) suggest that the enzyme is also repressed by $\mathbf{P i}$, but only in sorocarps. In Escherichia coli the alkaline phosphatase is both inhibited and repressed by $\mathbf{P i}$ (Horiuchi, Horiuchi \& Mizuno, 1959; Torriani, 1960). Glucose, a known repressor of many enzymes (Neidhart \& Magasanik, 1956) causes the same decrease in enzyme concentration in the spores as $\mathrm{Pi}$. The rich medium, which contains glucose, $\mathrm{Pi}$ and peptone, is more powerful than glucose or $\mathrm{Pi}$ alone. Whether this depends on the combination of $\mathrm{Pi}$ and glucose or in part on the presence of some amino acid(s) in peptone (Cox \& MacLeod, 1963) is not known.

The alkaline phosphatase activity in vivo in Dictyostelium discoideum appears to be controlled by at least two systems: (1) End-product inhibition by Pi. This is perhaps most important when the organism differentiates under extreme conditions of starvation. (2) Repression. The accumulation of the enzyme in the sorocarps is inhibited by the presence of exogenous metabolites in the environment during development. Both systems appear to collaborate to ensure maximal alkaline phosphatase activity during culmination, i.e. when cellulose synthesis and the final differentiation into spores and stalk cells takes place. The conclusions are based on the assumption that the $\mathrm{Pi}$ concentration determined for the whole cell approximates the concentration for the enzyme in the cell. The significance of in vitro data with respect to in vivo conditions has been discussed elsewhere (Wright, 1964).

In the presence of exogenous adenosine or deoxyadenosine the alkaline phosphatase concentrations increased, but only in the sorocarps (Fig. 11). If this effect involves increased enzyme synthesis, considerable protein synthesis must occur in the spores. That this is the case was shown by Wright \& Anderson (1960).

The effect of the nucleosides could be due to one or both of the following mechanisms: (1) The inducer may not be adenosine or deoxyadenosine per se but AMP or dAMP formed inside the cells. (2) Another possibility is that the increase in enzyme concentration is due to the removal of the repressor, $\mathbf{P i}$, by the formation of AMP or dAMP from the base $+\mathrm{Pi}$. We cannot at present decide between these two interpretations. We can only point out that the time of increase in alkaline phosphatase in the presence of adenosine coincides with the time of decrease in intracellular Pi concentration.

A preliminary report of this work has been published, (Gezelius \& Wright, 1963). 
This work was supported by grant No. GM-08958-02 from the U.S. Public Health Service and an allocation for the American Cancer Society Institutional Grant (IN-42B) to the Massachusetts General Hospital. This is publication No. 1190 of the Cancer Commission of Harvard University.

One of the authors (K.G.) held a Fulbright Scholarship during the work.

\section{REFERENCES}

Bonner, J. T. (1959). The Cellular Slime Molds. Princeton, N.J.: Princeton University Press.

Bonner, J. D., Chrquoine, A. D. \& Kolderie, M. Q. (1955). A histochemical study of differentiation in the cellular slime molds. J. expt. Zool. 130, 133.

Cox, R. P. \& MacLeod, C. M. (1963). Repression of alkaline phosphatase in human cell cultures by cystine and cysteine. Proc. natn. Acad. Sci., U.S.A. 49, 504.

Dryer, R. L., Tammes, A. R. \& Routh, J. I. (1957). The determination of phosphorus and phosphatase with $N$-phenyl-p-phenylenediamine. J. biol. Chem. 225, 177.

EADIE, G. S. (1952). On the evaluation of the constants $V_{m}$ and $K_{m}$ in enzyme reactions. Science, 116, 688.

Fiske, G. H. \& SubbaRow, Y. (1925). The colorimetric determinations of phosphorus. J. biol. Chem. 66, 375.

Garen, A. \& Levinthat, C. (1960). A fine-structure genetic and chemical study of the enzyme alkaline phosphatase of $\boldsymbol{E}$. coli. Biochim. biophys. Acta, 38, 470.

Gezeuus, K. \& Wright, B. (1963). Alkaline phosphatase and inorganic phosphate in Dictyostelium discoideum. Bact. Proc. p. 68.

Heppex, L. A., Harkness, D. R. \& Hilmoe, R. J. (1962). A study of the substrate specificity and other properties of the alkaline phosphatase of Escherichia coli. J. biol. Chem. 237, 841.

Heppel, L. A. \& Hilmoe, R. J. (1951). Purification and properties of 5'-nucleotidase. J. biol. Chem. 188, 665.

Herman, E. C. \& Wright, B. E. (1959). A 5'-nucleotidase activated by ferrous iron. J. biol. Chem. 234, 122.

Horiuchi, T., Horiuchi, S. \& Mrzuno, D. (1959). A possible negative feedback phenomenon controlling formation of alkaline phosphomonoesterase in Escherichia coli. Nature, Lond. 183, 1529.

Kornberg, A. \& Pricer, W. E. (1951). Enzymic phosphorylation of adenosine and 2,6-diaminopurine riboside. J. biol. Chem. 193, 481.

Krichevsky, M. I. \& Wright, B. E. (1963). Environmental control of the course of development in Dictyostelium discoideum. J. gen. Microbiol. 32, 195.

KrivaneK, J. O. (1956). Alkaline phosphatase activity in the developing slime mold, Dictyostelium discoideum Raper. J. exp. Zool. 133, 459.

KrivaneK, J. O. \& KrivaneK, R. C. (1958). The histochemical localization of certain biochemical intermediates and enzymes in the developing slime mold, Dictyostelium discoideum Raper. J. exp. Zool. 137, 89.

LidDEL, G. U. \& Wright, B. E. (1961). The effect of glucose on respiration of the differentiating slime mold. Develop. Biol. 3, 265.

NeidHardt, F. C. \& Magasanik, B. (1956). The effect of glucose on the induced biosynthesis of bacterial enzymes in the presence and absence of inducing agents. Biochim. biophys. Acta, 21, 324.

RAPER, K. B. (1951). Isolation, cultivation and conservation of simple slime molds. Quart. Rev. Biol. 26, 169.

REIS, J. L. (1951). The specificity of phosphomonoesterases in human tissues. Biochem. $J$. 48, 548.

Schwartz, J. H. (1963). The phosphorylation of alkaline phosphatase. Proc. natn. Acad. Sci., U.S.A. 49, 871. 
Sulkowski, E., BJörk, W. \& LAskowski, M., SR. (1963). A specific and non-specific alkaline monophosphatase in the venom of Bothrops atrox and their occurrence in the purified venom phosphodiesterase. J. biol. Chem. 238, 2477.

Sussman, M. (1961). Cultivation and serial transfer of the slime mould Dictyostelium discoideum in liquid nutrient medium. J. gen. Microbiol. 25, 375.

TornianI, A. (1960). Influence of inorganic phosphate in the formation of phosphatases by Escherichia coli. Biochim. biophys. Acta, 38, 460.

Whiteley, H. R. \& OISHI, M. (1963). An increase in alkaline phosphatase in an in vitro system derived from Bacillus subtilis. Biochem. biophys. Res. Comm. 13, 6.

Wright, B. E. (1960). On enzyme-substrate relationships during biochemical differentiation. Proc. natn. Acad. Sci., U.S.A. 46, 798.

Wright, B. E. (1964). Biochemistry of Acrasiales. In Biochemistry and Physiology of Protozoa. Ed. by S. Hutner, vol. 3. New York: Academic Press.

Wright, B. E. \& ANDerson, M. L. (1960). Protein and amino acid turnover during differentiation in the slime mold. II. Incorporation of $\left.{ }^{35} \mathrm{~S}\right]$ methionine into the amino acid pool and into protein. Biochim. biophys. Acta, 43, 67.

Wright, B. E. \& BARD, S. (1963). Glutamate oxidation in the differentiating slime mold. I. Studies in vivo. Biochim. biophys. Acta, 71, 45.

Wright, B. E., BrüHmüller, M. \& WARd, C. (1964). Studies in vivo on hexose metabolism in Dictyostelium discoideum. Develop. Biol. 9, 287.

Zamentof, S. (1957). Preparation and assay of deoxyribonucleic acid from animal tissue. Meth. Enzymol. 3, 696. 
